Editorial

\title{
Editor's Introduction: The Promise and Peril of Ranked Choice Voting
}

\author{
Caroline J. Tolbert * and Daria Kuznetsova \\ Department of Political Science, University of lowa, lowa City, IA 52442, USA; E-Mails: caroline-tolbert@uiowa.edu (C.J.T.), \\ daria-kuznetsova@uiowa.edu (D.K.) \\ * Corresponding author
}

Submitted: 19 April 2021 | Published: 15 June 2021

\begin{abstract}
Dissatisfaction with two-party politics is at an all-time high in the US. As extreme polarization and minority rule persist, a possibility of an electoral reform becomes increasingly more likely. This editor's introduction discusses the ranked choice voting (RCV) as an alternative to the current single-member geographic districts with winner-take-all plurality elections in the US. The articles for this thematic issue critically evaluate whether RCV lives up to its promise in improving democracy in the US. Like any rule or institutional change, it has benefits and drawbacks. The empirical and historical research presented here focuses on the implementation and use of RCV in the US compared to other countries. This thematic issue offers new insights into the promise and perils of RCV as a way to aggregate votes in elections that ensure that the winning candidate receives a majority of the votes cast.
\end{abstract}

\section{Keywords}

alternative vote; electoral system; democracy; multipartism; plurality elections; polarization; proportional representation; ranked choice voting; single transferable vote; two-party system

\section{Issue}

This editorial is part of the issue "The Politics, Promise and Peril of Ranked Choice Voting" edited by Caroline Tolbert (University of lowa, USA).

(C) 2021 by the authors; licensee Cogitatio (Lisbon, Portugal). This editorial is licensed under a Creative Commons Attribution 4.0 International License (CC BY).

\section{Introduction}

Dissatisfaction with two-party politics is at an all-time high in the US. A 2021 Gallup poll reports 62\% of Americans believe the Democratic and Republican parties are doing such a poor job of representing their constituents and that a third party is needed (Jones, 2021). An equal number believe change to the 'fundamental design and structure' of the US government is necessary (Pew Research Center, 2018). Today 4 in 10 Americans do not identify with either of two parties, labeling themselves political independents (Gallup, 2021; although scholars find that many independents lean toward one of the two parties and in two-party elections vote like partisans; see Keith, Magleby, Nelson, Orr, \& Westlye, 1992; Klar \& Krupnikov, 2016). Because campaigns are more likely to mobilize voters who are registered with the parties (Hersh, 2015), political independents in plurality election systems are less likely to be contacted or to vote in elec- tions. They also have lower political efficacy (Donovan \& Bowler, 2004). Proportional electoral systems generally create more equitable outcomes between political parties and encourage wider social group representation.

The predominance of just two major political parties in the US is the result of election rules-single-member geographic districts with winner-take-all plurality elections. This means the candidate with the most votes in a district wins public office, even if that individual wins less than a majority $(50 \%+1)$ of the votes cast. This is commonly referred to as Duverger's law, which holds that plurality rule elections within single-member districts tend to favor a two-party system (Duverger, 1954). If election rules change, outcomes may change the number of viable political parties. Electoral reform is possible if a majority of elected officials believe they will benefit under a new system (Boix, 1999; Drutman, 2020) or if reform is adopted directly by voters via an initiative or referendum (Bowler \& Donovan, 2000). The latter is 
how ranked choice voting (RCV) was adopted statewide in Maine and Alaska. The Framers of the US Constitution were silent on whether winner-take-all, pluralities or majorities should decide elections.

Some argue the main problem with the current system in the US is that it forces the entire spectrum of political opinions into just two camps. Pew's political typology has consistently identified at least nine distinct ideologies or groups using extensive nationwide polling (Pew Research Center, 2017). The ideological space between Democrat socialists like Bernie Sanders and President Joe Biden who represents the Democratic party's traditional moderate-liberal wing is one example. Likewise, there are large ideological gaps between right-wing populists like former President Donald Trump and mainline pro-business Republicans like Utah Senator Mitt Romney (Donovan \& Redlawsk, 2018). But with simple-majority (i.e., plurality) election rules, individuals are forced to vote for one of the two party candidates (Democrats or Republicans) or essentially throw away their vote, as smaller parties almost never have enough votes to win office. If third parties do get even a small share of the vote, it can wreak havoc on the two-party system. Because of this, nearly one-third of US presidents since the Civil War were elected with less than $50 \%$ of the popular vote (Donovan \& Bowler, 2004).

The US is at a tipping point because of extreme political polarization (Abramowitz, 2018). A July 7, 2020 Gallup poll found an 89-percentage-point difference between Republicans' and Democrats' ratings of then President Trump. This was the largest partisan gap Gallup ever measured for presidential approval in a single survey dating back to 1936 . Political polarization in the US is acerbated by high residential partisan segregation, where most Democrats living in urban, suburban or rural areas (high, medium or low density) rarely interact with Republicans, and vice versa (Brown \& Enos, 2021). The result is that there is nothing pulling candidates to the middle to appeal to a mixture of voters.

This severe polarization of US politics was not evident in the middle of the 20th century. Drutman (2020) argues that in the mid-1950s-mid-1990s the political system in the US had de-facto a four-party system with both Democrats and Republicans splitting into liberal and conservative wings. This de facto existence of four parties partially explains why the democratic system in the US worked sufficiently during that time. Today, however, toxic (affective, emotional, tribal) partisanship escalates the political divide (Mason, 2018). For some, the only way to de-escalate politics is to split up the two major parties and introduce more central parties to American politics, parties that can fill in the ideological vacuum in the middle of the political spectrum.

\section{Ranked Choice Voting}

One popular reform to give voters more choice of candidates and parties is RCV or instant run-off voting; in other countries this is offered referred to as the Alternative Vote. While Drutman (2020) advocates for RCV combined with multi-member districts to create a form of proportional representation (PR), growing local and statewide use of RCV with single member districts in the US offers one avenue for reform. RCV is similar to the Single Transferable Vote which allows voters to rank candidates on an election ballot in order of preference, rather than cast a single ballot for most preferred choice. Voters can choose third party or independent candidates and not risk throwing away their vote. RCV could reduce political polarization in America by giving candidates incentives to campaign for 2 nd and 3rd place votes, and not alienate voters whose first choice is someone else (Grofman \& Bowler, 1996). RCV may favor politicians that are more centrist because they can win with many second-place votes from both parties. The centrist candidates would then be able to mend the ideologically fractured country back together. RCV is designed to produce a majority winner within single or multimember districts.

RCV can be seen as a compromise of the current plurality system in the US and pure PR systems found in other countries. RCV or instant run-off voting may be better than two-round elections for several reasons. First, the elections are more likely to result in a widely acceptable leader with a broader base of support (although this is not guaranteed; Richie, Oestericher, Otis, \& Seitz-Brown, 2021). Second, voters do not need to make complicated strategic calculations, choose the lesser of two evils, or be concerned their votes might be wasted because they can express multiple preferences (but see Santucci, 2021, for possible limitations). RCV may save governments money to avoid fielding multiple elections (Drutman, 2020, pp. 182-183). The advantages of RCV can include higher youth participation (see Juelich \& Coll, 2021) and representation for women in public office (Terrell, Lamendola, \& Reilly, 2021). When survey respondents actually rank candidates, Coll (2021) finds most demographic groups, including racial and ethnic minorities, find ranking easy (see Donovan, Tolbert, \& Gracey, 2019, and experimental research by Maloy \& Ward, 2021). While RCV may result in higher involvement of constituencies in politics and elections, existing party elites may oppose reform if their candidates fail to consistently win under the new rules (Santucci, 2021). Yet Reilly (2021) shows how candidate and party endorsements influence voters' rankings in Australia and can, over time, promote reciprocal ranking exchanges between parties building support for the process and reducing negative campaigning (see Kropf, 2021 on slates of candidates).

\section{Why Does Ranked Choice Voting Matter Now? Democratic Backsliding and Political Polarization}

Why does RCV matter now? Because US political parties are more polarized. In the 2016 presidential election, Donald Trump won the Republican primaries with $38 \%$ 
of the votes cast in the first 33 states to vote. In the end, he won $45 \%$ of the votes in Republican primaries (Richie et al., 2021). Because no candidate had more votes, he was the Republican party nominee. Under the Electoral College and plurality voting rules (two states allocate proportionally), Trump was elected president in 2016 despite winning 3 million votes fewer nationwide than his Democratic opponent. This is minority rule (Owen, 2020). This same outcome occurred in the 2000 presidential election when George W. Bush was elected president and lost the popular vote. In 2024 or 2028 another populist candidate outside of the mainstream-possibly with little previous experience in politics - might win just $40 \%$ support in state-by-state primaries. He or she might again fail to win a majority of the popular vote in the general election but could be elected president. If winning candidates continue to lose elections (defined by losing the popular vote), will the citizens still support the government?

Other states/countries learned the hard way and changed their election system after a war or an authoritarian leader. The US does not have safeguards to prevent candidates that don't win a majority of votes in an election from taking office as the parties lost their gatekeeping function after the 1972 election with the shift to binding primaries (Levitsky \& Ziblatt, 2018, pp. 50-51). This becomes more of a concern when far-right factions (or in the future, far-left factions) take hold within one of the two mainstream political parties.

Warnings that the US could backslide toward an autocracy were driven in part by the Republican party's shift away from democratic norms and practices during President Trump's presidency (2016-2020). Backsliding is used to describe a crisis of democracies, as authoritarian leaders and military governments gain new ground globally. In 2021, Freedom House reported that scores of democratic freedoms dropped for the 15th straight year, as many countries restricted privacy rights to fight the pandemic (Coppedge et al., 2021; Pemstein et al., 2021). The Polity $V$ score codes the characteristics of countries in the world on a comparative rating scale from autocracy to democracy. Covering 167 countries from 1800-2020 with a population of over half a million people, Polity measures six components such as qualities of executive recruitment, constraints on executive authority and political competition. Emphasis is placed on constraints of elites-how much the president is checked by parliament.

The Polity score measures government authority on a 21-point scale from -10 (hereditary monarchy) to +10 (consolidated democracy). These scores are often converted into three regime groups: 'autocracies' $(-10$ to -6$)$, 'anocracies' $(-5$ to +5$)$, and 'democracies' $(+6$ to +10$)$. In 2020, the US dropped below the democracy threshold on the Polity scale to an anocracy/partial democracy (Center for Systemic Peace, n.d.). Factors that contributed to the drop included extreme political polarization and President Trump's unwillingness to cooper- ate with congressional oversight during the impeachment. Additional factors were Trump's challenge of the 2020 presidential election results, undermining public trust in democratic elections. The more rigorous $\mathrm{V}$-Dem electoral democracy score ranges from 0 to 1 . The US score dropped from .894 to .815 between 2016 and 2020 (Coppedge et al., 2021; Pemstein et al., 2021). While the US Polity or V-Dem scores may bounce back, the change signifies a perception of political instability or a tipping point. How much do election rules have to do with the quality of democracy?

\section{Do Election Rules Matter?}

Election rules matter-they are the rules of the game. Free, fair, and competitive elections are the minimum necessary condition for democracy. Electoral processes and rules, therefore, are the foundations of democratic regimes. When it comes to attempts at strengthening democracy in transitioning countries or nonconsolidated democracies, changes to electoral rules are often a main solution. The two main types of electoral systems-plurality (or a special case of it: majoritarian) and proportional-exist in different political environments and are designed to produce two different political outcomes. While plurality systems promote single-party governments with two major parties on the political spectrum, proportional systems encourage power-sharing by generating governments with multiple parties and party coalitions. As a result, majoritarian systems provide more democratic accountability and proportional systems provide more diversity and representation (Norris, 2004).

The observation that the simple plurality electoral systems tend to produce two-party systems was noted in Duverger's Law (Duverger, 1954, p. 217, as cited in Cox, 1997, p. 14). In contrast, Duverger's Hypothesis states that "the simple-majority system with second ballot and PR favors multipartyism" (Duverger, 1954, p. 239). Numerous studies of electoral systems provide empirical evidence to support these arguments (Boix, 1999). Interestingly, the US is the only example of the 'pure' Duverger's law existence in practice, because Britain, Canada, and India-countries with firstpast-the-post elections-have small but persistent third or even fourth parties (Bowler, Grofman, \& Blais, 2009; Grofman, Bowler, \& Blais, 2009). Nevertheless, the electoral rules do matter for the number of parties in the parliament, party behavior, as well as voters' behavior. By adopting one or another electoral system states can 'control' the number of major parties in the political arena (Norris, 2004).

Norris (2004) finds that, in general, political parties in PR electoral systems appeal to a particular sector of the electorate, develop tight social networks and connections with their voters, and compete within a diverse and dispersed political spectrum, as each party occupies a particular sector of political ideology. PR systems are 
associated with higher voter turnout and greater satisfaction with democracy (Karp, Banducci, \& Bowler, 2003). In majoritarian systems, parties face higher electoral hurdles, appeal to diverse sectors of the electorate, concentrate on overreaching issues (efficient public services, economic growth, defense, etc.), and are usually located in the center of the political spectrum, as well as the center for social and ideological issues. Norris (2004) also finds that social cleavages are weaker in majoritarian systems.

If we compare the summary of the majoritarian systems provided by Norris (2004) with the political realities in the US, it becomes clear that the two-party system of the US is an outlier. With the increasing political polarization, the major parties in the US (at least the Republican party) are moving further away from the center of the ideological spectrum, reinforcing already strong social cleavages (Mason, 2018). These outcomes are not typical for majoritarian systems and, it can be argued, contribute to the current democratic struggles reflected in the recently released democratic indices, such as V-Dem and the Polity score.

\section{Are Multiparty Systems Better?}

While multiparty systems provide clear benefits, it is important to consider some of the potential drawbacks. The major issue with multiparty democracy, the issue that has been salient in Europe in recent years, is that multiparty systems allow extremist parties to enter the government. While this may be a negative consequence, Drutman (2020) argues that the representation of extremist parties is a good thing. It provides "a platform to vent and defuse grievances and let[s] other parties adjust in response" (p. 207). This representation may lead to more transparency in extremist party's actions, predictability, and accountability. It may limit the party's influence of otherwise marginalized segments of the society. This is a better outcome than when a "hardline minority fraction [that] redefined the modern Republican Party" (Drutman, 2020, p. 207) gains the control over the presidency or a branch of Congress.

When extremist parties enter governments, their size matters to the extent of the influence. As we saw in the US, the control of the Republican party, one of the two major parties, by a minority of the population translated into the minority control of American politics. With the multiparty system, minority control is close to impossible.

Even with the rise of the popularity of the farright parties in Western Europe, most of them remain with a small representation in the parliaments. Sweden Democrats, a nationalist and right-wing populist political party in Sweden, is one of eight parties currently represented in the Riksdag during the 2018-2022 electoral period. In 2018 the party won 62 out of 349 seats (17.8\%) in the parliament (Riksdagsförvaltningen, n.d.). This is the largest number of seats Sweden Democrats have won since they first entered the Riksdag in 2010 after overcoming the $4 \%$ electoral threshold. In Germany, the Alternative for Germany (AfD), a nationalist and right-wing populist political party, is third out of the six parliamentary groups in the Bundestag with 88 out of a total of 709 seats (12.4\%; German Bundestag, n.d.). With the exception of Hungary and Poland, where nationalist parties hold the majority of the seats in the parliaments, and Switzerland where The Swiss People's Party is the largest in the Federal Assembly (although they do not have the majority of the seats), the rest of nationalist political parties in Europe represent the minority. The benefits of multiparty systems may outweigh potential drawbacks of the emergence of an extremist party.

\section{Conclusions}

By a different metric than Polity or V-Dem scores, US democracy exhibited resiliency in the 2020 presidential election with historic voter turnout breaking a 120 -year record. Due to the coronavirus pandemic that increased efforts to avoid election day crowds, the mailbox became the ballot box. This milestone election saw nearly two-thirds of all votes cast early, roughly onethird of which were in-person at polling locations and two-thirds by mail. Research finds state election laws allowing mail/absentee voting, in person early voting and same-day registration, as well as updated election administration processes, can increase voter turnout, even for the most disadvantaged groups (Ritter \& Tolbert, 2020). Yet a national law to protect voting access has proven difficult, even under unified party control of the presidency and congress. In 2021, the US House of Representatives passed historic legislation (HR 1, For the People Act) to protect voting rights nationwide, but it is unlikely to be adopted by the US Senate or to become law. Post the 2020 election multiple states adopted laws to restrict use of mail/absentee voting. The US has a patchwork of laws for voting access, with variation across the 50 states.

Most agree US democracy faces challenges. RCV is one reform of the election system that has been proposed to ensure winning candidates a majority of the popular vote. The articles for this thematic issue critically evaluate whether RCV lives up to its promise. Like any rule or institutional change, it has benefits and drawbacks. The empirical and historical research presented here focuses on the implementation and use of RCV in the US compared to other countries. They offer new insights into the promise and perils of RCV as a way to aggregate votes in elections that ensure that the winning candidate receives a majority of the votes cast.

\section{Conflict of Interests}

The authors declare no conflict of interests. 


\section{References}

Abramowitz, A. (2018). The great alignment: Race, party transformation, and the rise of Donald Trump. New Haven, CT and London: Yale University Press.

Boix, C. (1999). Setting the rules of the game: The choice of electoral systems in advanced democracies. The American Political Science Review, 93(3), 609-624. https://doi.org/10.2307/2585577

Bowler, S., \& Donovan, T. (2000). Demanding choices: Opinion, voting, and direct democracy. Ann Arbor, MI: University of Michigan Press.

Bowler, S., Grofman, B., \& Blais, A. (2009). The United States: A case of Duvergerian equilibrium. In $\mathrm{S}$. Bowler, A. Blais, \& B. Grofman (Eds.), Duverger's law of plurality voting: The logic of party competition in Canada, India, the United Kingdom and the United States (pp. 135-146). New York, NY: Springer. https://doi.org/10.1007/978-0-387-09720-6_9

Brown, J. R., \& Enos, R. D. (2021). The measurement of partisan sorting for 180 million voters. Nature Human Behaviour, 2021. https://doi.org/10.1038/ s41562-021-01066-z

Center for Systemic Peace. (n.d.). Index. Center for Systemic Peace. Retrieved from www.systemicpeace. org/index.html

Coll, J. A. (2021). Demographic disparities using rankedchoice voting? Ranking difficulty, under-voting, and the 2020 Democratic primary. Politics and Governance, 9(2), 293-305.

Coppedge, M., Gerring, J., Knutsen, C. H., Lindberg, S. I., Teorell, J., Alizada, N., . . . Ziblatt, D. (2021). V-Dem country-year/country-date dataset v11.1 [Data set]. https://doi.org/10.23696/vdemds21

Cox, G. W. (1997). Making votes count: Strategic coordination in the world's electoral systems. Cambridge and New York, NY: Cambridge University Press.

Donovan, T., \& Bowler, S. (2004). Reforming the republic: Democratic institutions for the new America. Upper Saddle River, NJ: Pearson/Prentice Hall.

Donovan, T., \& Redlawsk, D. (2018). Donald Trump and right-wing populists in comparative perspective. Journal of Elections, Public Opinion and Parties, 28(2), 190-207. https://doi.org/10.1080/17457289. 2018.1441844

Donovan, T., Tolbert, C., \& Gracey, K. (2019). Selfreported understanding of ranked-choice voting. Social Science Quarterly, 100(5), 1768-1776. https:// doi.org/10.1111/ssqu.12651

Drutman, L. (2020). Breaking the two-party doom loop: The case for multiparty democracy in America. New York, NY: Oxford University Press.

Duverger, M. (1954). Political Parties. New York, NY: Wiley.

Gallup. (2021). Party affiliation. Gallup. Retrieved from https://news.gallup.com/poll/15370/PartyAffiliation.aspx

German Bundestag. (n.d.). Parliamentary groups.
German Bundestag. Retrieved from https://www. bundestag.de/en/parliament/groups

Grofman, B., \& Bowler, S. (1996). STV's place in the family of electoral systems: The theoretical comparisons and contrasts. Representation, 34(1), 43-47. https:// doi.org/10.1080/00344899608522985

Grofman, B., Bowler, S., \& Blais, A. (2009). Introduction: Evidence for Duverger's law from four countries. In S. Bowler, A. Blais, \& B. Grofman (Eds.), Duverger's law of plurality voting: The logic of party competition in Canada, India, the United Kingdom and the United States (pp. 1-11). New York, NY: Springer. https:// doi.org/10.1007/978-0-387-09720-6_1

Hersh, E. (2015). Hacking the electorate: How campaigns perceive voters. New York, NY: Cambridge University Press.

Jones, J. M. (2021, February 15). Support for third U.S. political party at high point. Gallup. Retrieved from https://news.gallup.com/poll/329639/supportthird-political-party-high-point.aspx

Juelich, C. L., \& Coll, J. A. (2021). Ranked choice voting and youth voter turnout: The roles of campaign civility and candidate contact. Politics and Governance, 9(2), 319-331.

Karp, J. A., Banducci, S. A., \& Bowler, S. (2003). To know it is to love it? Satisfaction with democracy in the European Union. Comparative Political Studies, 36(3), 271-292. https://doi.org/10.1177/ 0010414002250669

Keith, B. E., Magleby, D. B., Nelson, C. J., Orr, E. A., \& Westlye, M. C. (1992). The myth of the Independent voter. Berkeley, CA: University of California Press.

Klar, S., \& Krupnikov, Y. (2016). Independent politics: How American disdain for parties leads to political inaction. New York, NY: Cambridge University Press.

Kropf, M. (2021). Using campaign communications to analyze civility in ranked choice voting elections. Politics and Governance, 9(2), 280-292.

Levitsky, S., \& Ziblatt, D. (2018). How democracies die (Trade paperback). New York, NY: Viking Press.

Maloy, J. S., \& Ward, M. (2021). The impact of input rules and ballot options on voting error: An experimental analysis. Politics and Governance, 9(2), 306-318.

Mason, L. (2018). Uncivil agreement: How politics became our identity. Chicago, IL, and London: The University of Chicago Press.

Norris, P. (2004). Electoral engineering: Voting rules and political behavior. Cambridge and New York, NY: Cambridge University Press.

Owen, K. (2020, December 2). Minority rule cannot last in America. The Atlantic. Retrieved from https://www.theatlantic.com/ideas/archive/2020/ $12 /$ minority-rule-cannot-last-america/617272

Pemstein, D., Marquardt, K. L., Tzelgov, E., Wang, Y., Medzihorsky, J., Krusell, J., . . . von Römer, J. (2021). The V-Dem measurement model: Latent variable analysis for cross-national and cross-temporal expertcoded data (V-Dem Working Paper No. 21, 6th edi- 
tion). Gothenburg: Varieties of Democracy Institute.

Pew Research Center. (2017, October 24). Political typology reveals deep fissures on the Right and Left. Pew Research Center. Retrieved from https://www. pewresearch.org/politics/2017/10/24/politicaltypology-reveals-deep-fissures-on-the-right-and-left

Pew Research Center. (2018, April 26). The public, the political system and American democracy. Pew Research Center. Retrieved from https://www. pewresearch.org/politics/2018/04/26/1-democracyand-government-the-u-s-political-system-electedofficials-and-governmental-institutions

Reilly, B. (2021). Ranked choice voting in Australia and America: Do voters follow party cues? Politics and Governance, 9(2), 271-279.

Richie, R., Oestericher, B., Otis, D., \& Seitz-Brown, J.
(2021). Lessons from the use of ranked choice voting in American presidential primaries. Politics and Governance, 9(2), 354-364.

Riksdagsförvaltningen. (n.d.). Members and parties. Riksdagsförvaltningen. Retrieved from https://www. riksdagen.se/en/members-and-parties

Ritter, M., \& Tolbert, C. J. (2020). Accessible elections: How the states can help Americans vote. New York, NY: Oxford University Press.

Santucci, J. (2021). Variants of ranked-choice voting from a strategic perspective. Politics and Governance, 9(2), 344-353.

Terrell, C. R., Lamendola, C., \& Reilly, M. (2021). Election reform and women's representation: Ranked choice voting in the U.S. Politics and Governance, 9(2), 332-343.

\section{About the Authors}

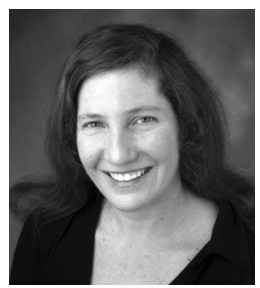

Caroline J. Tolbert is the Lowell C. Battershell University Distinguished Professor of Political Science at the University of lowa. Her work is driven by an interest in strengthening American democracy and increasing political participation. She is the coauthor of Accessible Elections: How the States can Help Americans Vote (Oxford, 2020) on absentee/mail voting, early voting and same-day registration.

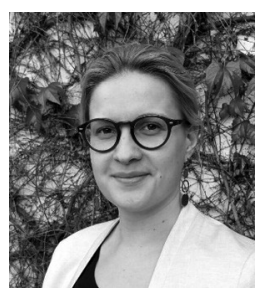

Daria Kuznetsova is a PhD Student at the University of lowa. She studies how new media impacts political participation, political support, and perceptions of democracy cross-nationally. Additional research interests include government decentralization and how decentralization policies affect the quality and access to public services. 